men to the voluntary hospitals and double the staff of such. This number can be increased by 10,000 in one week by appointing local district visiting staffs. At Liverpool the majority of the visiting doctors are entitled to charge full fees to hospital patients occupying pay beds and pay wards. Local doctors will not be excluded from making a fair wage if appointed. Only a little common sense is required to meet the "scarcity of doctors" bogey. Will the "men in possession" agree?

I am, Sir, yours faithfully,

Liverpool, Feb. 8th, 1915. R. R. Rentoul, M.D.

\section{TUBERCULIN TREATMENT OF PULMONARY TUBERCULOSIS.}

\section{To the Editor of THE LANCET.}

SIR,-In Dr. E. G. Glover's communication on this subject in THE LANCET of Feb. 6th occurs the following statement:-

There is one other point which deserves notice, although perhaps it is a minor one, and it is that the dangers noted after reactions-i.e., extension of disease, increased activity, pleurisy, and pneumothorax-are unfortunately, as the Registrar-General will testify, the dangers of the disease itself.

Such a remark has no bearing on the danger or otherwise of administering tuberculin. No sound critic of tuberculin ever imputed to tuberculin a capacity to do more than increase the disease, and because the disease spreads and produces the above results in many untreated cases, this in no way removes tuberculin from the list of agents which may hasten the above calamities.

I am, Sir, yours faithfully,

Ayrshire Sanatorium, Feb. 6th, 1915. EDWard E. PrEST.

\section{LEECHES AND THE WAR.}

\section{To the Editor of THE LANCET.}

SIR,-With regard to Mr. J. D. Marshall's offer in The LANCET of Feb. 6th, it may be of interest to state that leeches of the official variety are obtainable to a limited extent through the ordinary trade channels at a cost less than one-fourth that mentioned by Mr. Marshall for Limnatis granulosa. This institution received a small number of leeches of French origin this week.

I am, Sir, yours faithfully,

London Hospital, Feb. 6th, 1915. F. A. HockING. ** But the price of a leech might vary with its capacity.ED. $\mathrm{L}$.

\section{THE DEARER LOAF.}

\section{To the Editor of THE LANCET.}

SIR,-As a result of the appearance of your leading article with this title on Jan. 30th, I have been asked by the Corn Products Company, Limited, to forward you some loaves made from a mixture of wheaten flour and cornflour. My son, Mr. William C. Jago, who now controls the Jago Laboratories, has had some loaves baked for me in a test bakery. Samples of these, numbered 1, 2, 3, and 4, were forwarded to you yesterday.

The following are particulars of the mixtures from which the respective loaves were made: 1. London Town household flour only, with salt, yeast, and water. 2. Mixture of 90 parts same flour with 10 parts cornflour; in addition gelatinised cornflour at the rate of $4 \mathrm{lb}$. to the sack of $280 \mathrm{lb}$, and dry corn starch sugar at the rate of $21 \mathrm{~b}$. to the sack were used. Other ingredients as before. 3. Mixture of 80 parts same flour with 20 parts cornflour. Additions, \&c., as in No. 2. 4. Mixture of 66 parts same flour with 20 parts cornflour and 14 parts peaflour. Additions, \&c., as in No. 2. The volumes of the resultant loaves, each made from 560 grammes of the flour or flour mixture, were as follows: (1) 2839 c.c.; (2) 2676 c.c.; (3) 2593 c.c.; (4) 2022 c.c. The mixed flour loaves were all smaller than that from unmixed flour, but in every case they were of fair volume and good open texture. The loaves themselves will, however, best show you the general characters of the resultant bread. I think you will agree that in colour and general appearance Nos. 2 and 3 are fairly equal to No. 1, and would prove quite as digestible. The employment of No. 2 mixture would increase the available supply of breadstuffs from 100 parts to 111 parts, while in the case of No. 3 the increase would be from 100 parts to 125 parts.

In the case of No. 4 the object of the experiment was somewhat different-viz., to prepare bread that should have about the same protein value as the white flour used in the preceding mixtures. A sample of the flour yielded 10 per cent. of protein on analysis. Taking the protein content of peaflour at 25 percent., a mixture of two parts of peaflour to three parts of cornflour would also contain 10 per cent. of protein, and might therefore be used in any desired proportion with the wheaten flour without altering its protein content. In the case of No. 4, two parts of wheaten flour were taken to one part of the pea and corn flour mixture. This represents a somewhat large addition to a flour which, to start with, was somewhat on the weak side. The dough was naturally very friable in the handling, but never. theless made a fair loaf. Again, the sample itself will best show you the nature of the bread. (In all cases please make allowance for the staleness and effects of packing on the loaves when they reach you.) I think you will agree that this bread is not at all un. pleasant in either appearance or flavour. Judging from its physical character I should say such bread would be very digestible and its proteins capable of very good absorption. In all probability the ratio of absorption would be slightly higher than is the case of the white bread. The use of such a mixture, if necessity arose, would raise the amount of available bread-stuffs from 100 to 150 parts and with no loss of nutritive value.

At present market prices the No. 4 mixture works out slightly lower in price than the flour. There is not likely to be any shortage in the world's supply of cornflour, and in addition to peas there are lentils and soya beans to draw on as auxiliary sources of protein. The latter especially is exceedingly rich in flesh formers, and yields a flour which is light in colour and of pleasant flavour. I am, Sir, yours faithfully,

Hove, Sussex, Feb. 6th, 1915. WILLIAM JAGO.

** The results are quite interesting. The loaves received appeared to us to be quite acceptable in regard to texture, flavour, and appearance.-ED. L.

LONDON UNIVERSITY EXaminations AND THE New Pharmacopcaia. - The regulations for the second examination for medical degrees, Part II., have been amended by the insertion of the following footnote: At the examinations in pharmacology held in March and July, 1915, students will be permitted to base their replies either on the old or on the new edition of the Pharmacopoeia provided that they shall be required to state on which edition such replies are based. In and after March, 1916, replies must be based on the new edition of the Pharmacopoeia. 